\title{
ASPECTOS ANATÔMICOS E ADAPTATIVOS DAS PARTES VEGETATIVAS DE SPARTINA DENSIFLORA BRONG. (GRAMINEAE) DA MARISMA DO ESTUÁRIO DA LAGOA DOS PATOS-RS.
}

\author{
Mara Perazzolo ${ }^{1}$ \\ Fátima Pinheiro
}

Recebido em 28/12/90. Aceito em 12/12/91

\begin{abstract}
RESUMO: Spartina densiflora Brong.é uma gramínea típica das marismas doestuário da lagoa dos Patos, Rio Grande do Sul, Brasil. A espécie apresenta adaptaçōes morfoanatômicas em relação à salinidade, inundaçāo e condiçōes anaeróbicas que caracterizam este ambiente estressante. As adaptaçōes xeromórficas e halofíticas desta espécie são a presença de estômatos protegidos por papilas; alta lignificação nas folhas, rizoma e raízes; enrolamento foliar e glândulas secretoras de sal. Como adaptação à sobrevivência ao solo anaeróbico, a espécie apresenta espaços intercelulares ras folhas, rizoma e raízes.
\end{abstract}

Palavras-chave: Spartina densiflora, anatomia, anaerobiose, halófita, xerófita.

ABSTRACT: Spartina densiflora Brong. is a typical grass in salt marshes of the Patos lagoon estuary, Rio Grande doSul, Brazil. The species shows morphological adaptations in relation to salinity, flooding and, anaerobic soils, characteristic for this stressful environment. The principal xerophytic and halophytic adaptations observed in this species are lenghwise curling of the leaves with stomates protected by papilla; increased lignification in the leaves, rhyzomes, roots and salt glands spread. The presence of intercellular spaces in the leaves, rhyzomes and roots is an adaptation that permits the plants survival in anaerobic soils.

Key words: Spartina densiflora, anatomy, anaerobiosis, halophyte, xerophyte.

\section{Introdução}

Estudos relativos a Spartina densiflora Brong. abordam principalmente aspectos taxonômicos. Não foram encontrados na bibliografia disponível informações

\footnotetext{
${ }^{1}$ Departamento de Ciências Morfo Biológicas, Fundaçāo Universidade do Rio Grande, Caixa Postal 474, 09650-900 - Rio Grande-RS.
} 
sobre anatomofisiologia e adaptações ao ambiente, que se caracteriza por ser estressante, devido a alta salinidade e alagamento.

A morfoanatomia e os aspectos fisiólogicos são analisados por Sutherland \& Eastwood (1916) para Spartina townsendii Groves, e por Hansen et al. (1976) para Distichlis spicata (L.) Green. Andrade (1967) trata da anatomoecologia de Spartina ciliata Kunth., espécie característica de dunas, e Anderson (1974) e Dawes (1981) para espécies halófitas da marisma. Fahn(1974)descreve características xeromórficas de espécies de deserto e marisma, e Prisco (1980) relaciona o crescimento de plantas halófitas em condições de estresse salino.

Muitas halófitas apresentam estrutura de secreção de sal como glândulas ou micropêlos, os quais eliminam sais ativamente. A estrutura e função de glânduilas de sal de gramíneas foram inicialmente descritas para Spartina townsendii por Sutherland \& Eastwood (1916) e por Skelding \& Winterbotham (1939) e para o gênero Spartina, Fahn (1988). A análise da ultra-estrutura da glândula de sal de Spartina foliosa Trin. foi realizada por Levering \& Thomson (1971) e Thomson (1975), onde primeiro registram a presença de membranas divisórias na célula basal. Liphschitz \& Waisel (1982) relacionaram a eficiência da secreção de sal com tipos de glândulas de posição emergentes, semi-emergentes e aprofundadas na epiderme foliar das gramíneas examinadas. Oross et al. (1985) propuseram um modelo para explicar o mecanismo de secreção de sal em gramíneas, baseado na ultra-estrutura do gênero Cynodon Rich. Amarasinghe \& Watson $(1988,1989)$, a partir da análise ultra-estrutural de 17 gramíneas, determinaram três tipos morfológicos de micropêlos: cloridóide, panicóide e enapogóide. Com subsídios de microanálises complementares detectaram que secreção de sal ocorria somente no tipo cloridóide.

Os problemas de adaptação morfofisiológicos ao estresse do oxigênio para plantas que se desenvolvem em solos alagados são abordados por Dacey (1981) e Drew (1983).

Esse estudo propõe analisar Spartina densiflora anatomicamente para o melhor entendimento de sua adaptabilidade ao ambiente da marisma.

\section{Material e métodos}

Spartina densiflora foi coletada mensalmente durante o ano de 1987, sendo retirada do ambiente com parte do seu respectivo substrato e transportada em baldes plásticos para o laboratório. O material foi identificado e herborizado no laboratório de Botânica do Departamento de Ciências Morfo-Biológicas e incorporado ao Herbário da Universidade do Rio Grande (HURG).

Para análise anatômica foram utilizadas partes vegetativas (folhas, raízes e rizoma) em estágio de completo desenvolvimento.

Foram feitos cortes transversais a mão livre, no material fresco, nas folhas, rizoma, raízes, sendo usado Sudam IV para evidenciar materiais graxos em geral.

Para confecção de lâminas permanentes de folha, rizoma e raízes foram fixadas no fluído Worcester (Johansen 1940). A técnica de inclusão em parafina foi feita pelo 
método de Preece (Becak \& Paulete 1976) e seccionados com espessura de $15 \mu \mathrm{m}$ em cortes transversais não seriados. A coloração foi feita em Astrablau-AuraminaSafranina (Maácz \& Vágas 1961). As folhas escolhidas para confecção das lâminas permanentes, foram retiradas do primeiro nó acima do solo e que se apresentavam totalmente expandidas. Para os cortes determinou-se três zonas nas folhas: terço inferior, acima da lígula; terço superior, junto ao ápice; terço mediano. Também foram observados cortes feitos em folhas de nós superiores.

Foram realizadas raspagens para observação da superfície abaxial da folha $\mathrm{e}$ utilizou-se a técnica de Johansen (1940) para determinação de corpos silicosos nas células.

As estruturas foram analisadas e desenhadas em microscópio óptico com câmara clara e projetor de lâminas histológicas. Foram obtidas medidas através de régua micrometrada por transferência, sendo os valores referidos em micrômetros $(\mu \mathrm{m})$. As fotos foram feitas no fotomicroscópio JENAMED-2, marca Carl-Zeiss.

Dados ambientais: Aárea de estudo faz parte do habitat da marisma do estuário da lagoa dos Patos. Localiza-se no município do Rio Grande, RS, e situa-se a $32^{\circ} \mathrm{C} 09^{\prime} \mathrm{S}$ e $52^{\circ} 06^{\prime} \mathrm{W}$ (fig. 1 ).

O solo é areno-lodoso, e a espécie Spartina densiflora ocorre junto com Spartina alterniflora Loisel., Paspalum vaginatum Sw., Scirpus olneyi A. Gray., Fimbristylis spadicea (L.) Wahl., Juncus acutus L. e Salicornia gaudichaudiana Mog.

O fotoperíodo máximo é alcançado em dezembro e o mínimo em junho, com 14 e 10 horas, respectivamente (Coutinho, 1982).

D'Incao (com. pes.), que estuda a bioecologia de Casmagnathus granulata (crustáceo) no mesmo local de nosso trabalho, relata que os fatores ecológicos, salinidade, oxigênio e temperatura, apresentam considerável variação sazonal. Os resultados encontrados por este autor mostram que a saturação de oxigênio obtida nas tocas de $C$. granulata, que se abriga entre as raízes de Spartina densiflora, apresenta uma média de $49,8 \%$ para verão/outono e $29,0 \%$ para inverno/primavera.

As precipitações pluviométricas, segundo Saraiva (com. pes.), durante o inverno/primavera, atingem em média $145,6 \mathrm{~mm}$, o que provoca inundação da marisma e conseqüente diminuição da salinidade. A salinidade dentro das tocas do crustáceo atinge então o valor médio de $17,4 \%$. No período verão/outono a precipitação média é de $96,0 \mathrm{~mm}$, o nível da água diminui consideravelmente e a salinidade aumenta para $22,6 \%$. em média. A temperatura média, por sua vez; mostra um máximo de 28,0 graus centígrados para o mês de janeiro e o mínimo de 7,8 graus centígrados para junho.

\section{Resultados e Discussão}

Spartina densiflora caracteriza-se por ser cespitosa, com folhas longas e estreitas de consistência endurecida, observando-se seu enrolamento durante condições de seca físiológica. O rizoma é curto e endurecido com numerosas raízes longas 


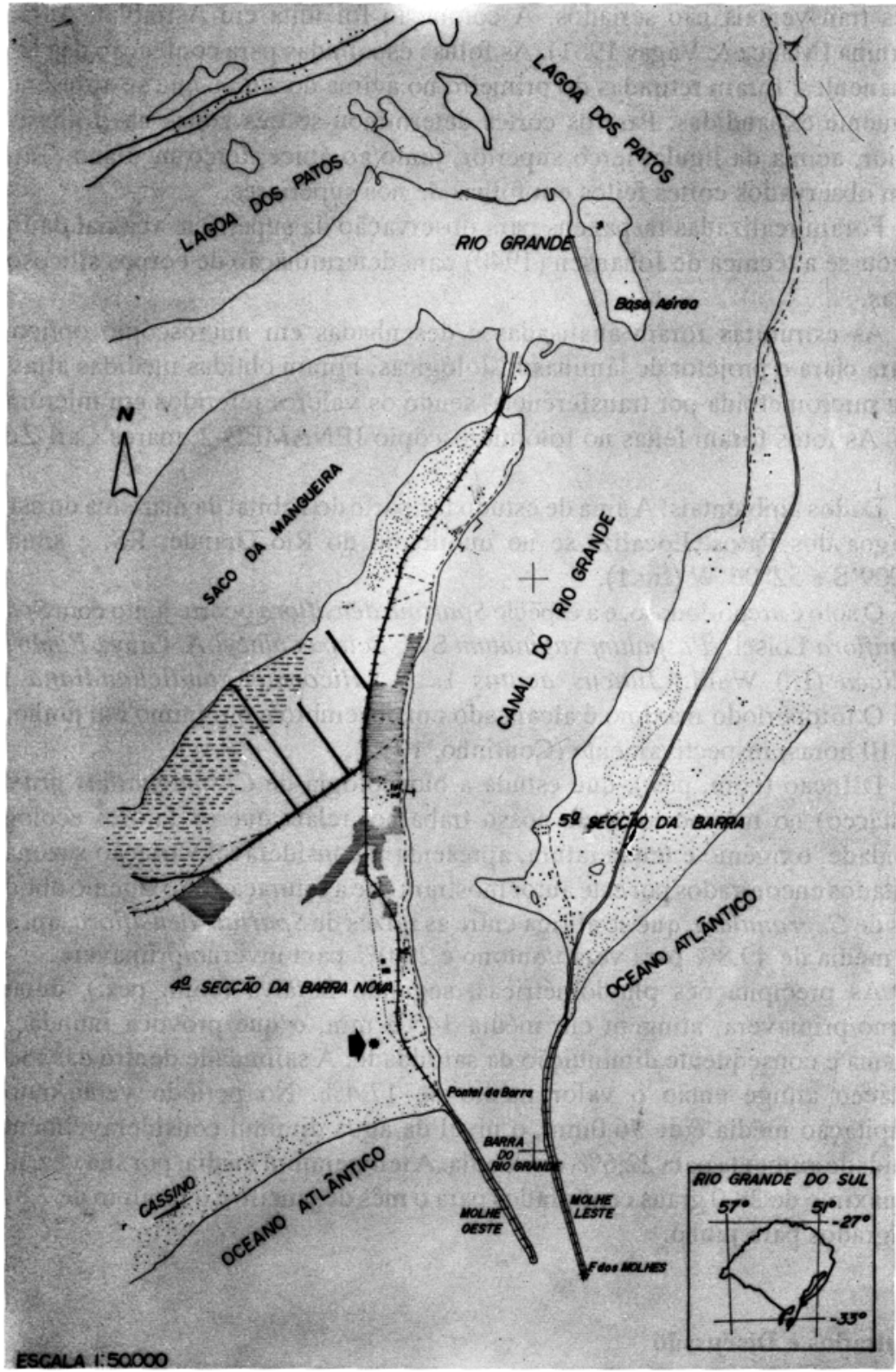

Figura 1: Mapa da regiāo das coletas. Estuário da Lagoa dos Patos, Rio Grande, Rio Grande do Sul. $\Rightarrow^{*}$ à k local de coleta. 
e curtas. As raízes longas são mais grossas, profundas e com a principal função de fixação da planta ao substrato. Apresentam-se com poucas ou nenhuma ramificação e pêlos asorventes. As raízes curtas são finas, possuem numerosas ramificações e pêlos absorventes, atuando principalmente na absorção e localizam-se nos primeiros dez centímetros do solo.

Lâmina foliar: Em vista frontal, a superfície abaxial da lâmina foliar apresenta células longas com numerosas pontuações e paredes celulares sinuosas. As células curtas, com corpos silicosos ocorrem aos pares e eventualmente simples, distribuindo-se regularmente nas faixas costais e intercostais, entre as células longas. As células curtas aos pares são silico-suberosas (Figura 2). Os corpos silicosos são em forma de halteres, e aparecem parcialmente encaixados nas células curtas de cortiça. Os estômatos e glândulas de sal ocorrem nas faixas intercostais, sendo que os primeiros são pequenos com células subsidiárias em meia lua e de distribuição descontínua ao longo da folha. As glândulas de sal, distribuídas irregularmente, aparecem em depressões delimitadas por quatro células epidérmicas (Figura 2).

Em corte transversal, a epiderme abaxial apresenta células de paredes espessadas, irregularmente intercaladas por células com corpos silicosos e com espessa camada cuticular. A superfície adaxial apresenta sulcos com ramificações, estas de diferentes tamanhos geralmente arredondadas e cobertas por papilas epidérmicas de
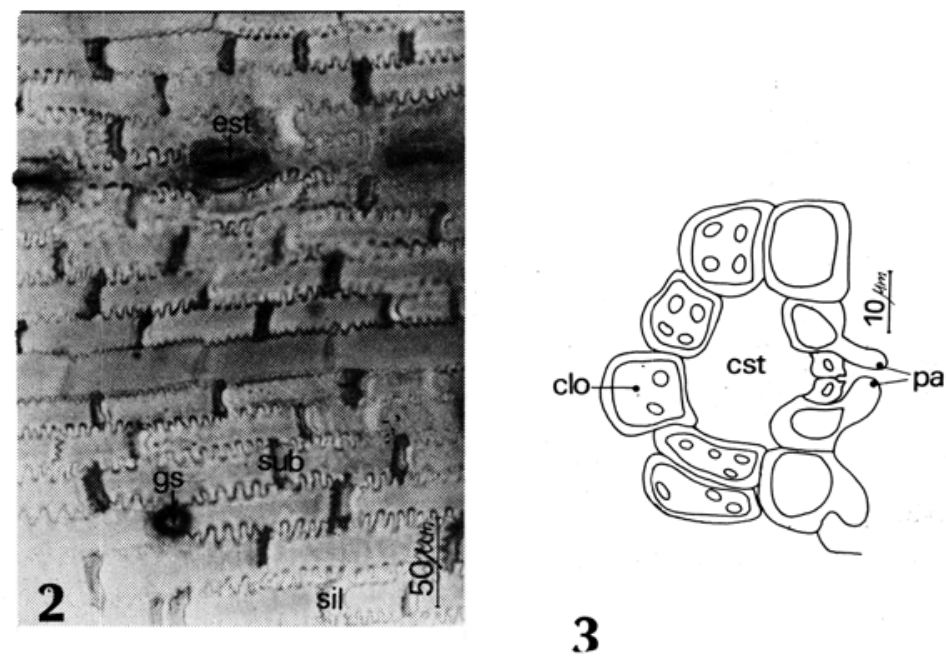

Figura 2: Spartina densiflora. Vista frontal da epiderme abaxial, mostrando células longas intercaladas com células curtas silico-suberosas. est: estômato; gs: glândula de sal; sil: célula com corpo silicoso; sub: célula suberosa.

Figura 3: Spartina densiflora. Corte transversal na zona mediana do estômato, da superfície adaxial da folha. cst: câmara substomática; clo: clorênquima; pa: papilas epidérmicas. 
diversas formas (simples, bifurcadas e arredondadas) com uma camada cuticular muito delgada. As células buliformes, localizadas na base dos sulcos, são três: arredondadas, a central maior e as laterais menores. Células buliformes se distinguem das demais células epidérmicas por apresentarem aspecto translúcido, turgescentes, com paredes celulares delgadas quando em contato com o clorênquima e levemente espessadas quando externas (figura 4). Os estômatos em ambas as superfícies são pequenos, sendo mais abundantes na superfície adaxial, onde localizam-se preferencialmente nas ramificações dos sulcos (Figura 4). As células estomáticas da epiderme adaxial são recobertas por papilas epidérmicas simples das células subsidiárias (Figura 3). As glândulas secretoras de sal presentes em ambas as epidermes, são mais abundantes nas ramificações dos sulcos da epiderme adaxial. Estas glândulas, são formadas por duas células, uma grande interna, célula basal, e outra pequena, célula apical (Figura $5 \mathrm{a} \mathrm{e} \mathrm{b).} \mathrm{A} \mathrm{célula} \mathrm{basal} \mathrm{apa} \mathrm{rece} \mathrm{em} \mathrm{contato} \mathrm{com} \mathrm{o} \mathrm{clorênquima} \mathrm{e} \mathrm{células}$ epidérmicas adjacentes. A porção superior da célula basal, que está em contato com a célula apical, apresenta um estreitamento que se assemelha a um "pescoço", região onde se pode observar citoplasma extremamente denso. Intensa granulação é

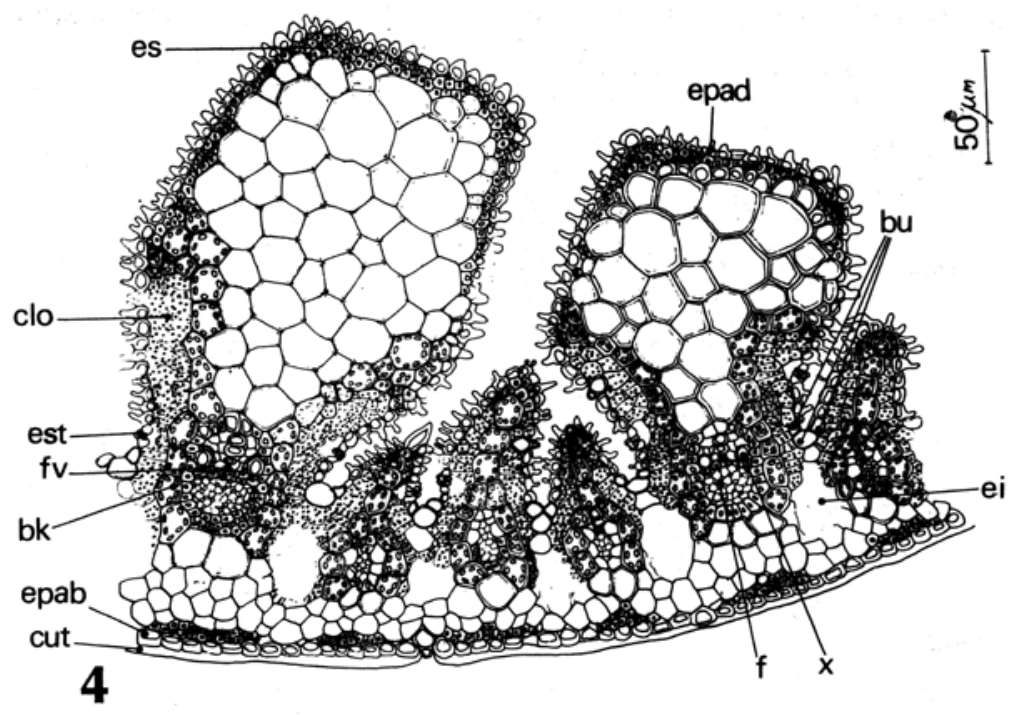

Figura 4: Spartina densiflora. Corte transversal do terço inferior da lâmina foliar. epad: epiderme adaxial; epab: epiderme abaxial; ei: espaços intercelulares; es: banda esclerenquimática; est: estômato; bk: bainha vascular do tipo "Kranz"; bu: células buliformes; clo: clorênquima; cut: cutícula; fv: feixe vascular; f: floema; $\mathrm{x}$ : xilema. 


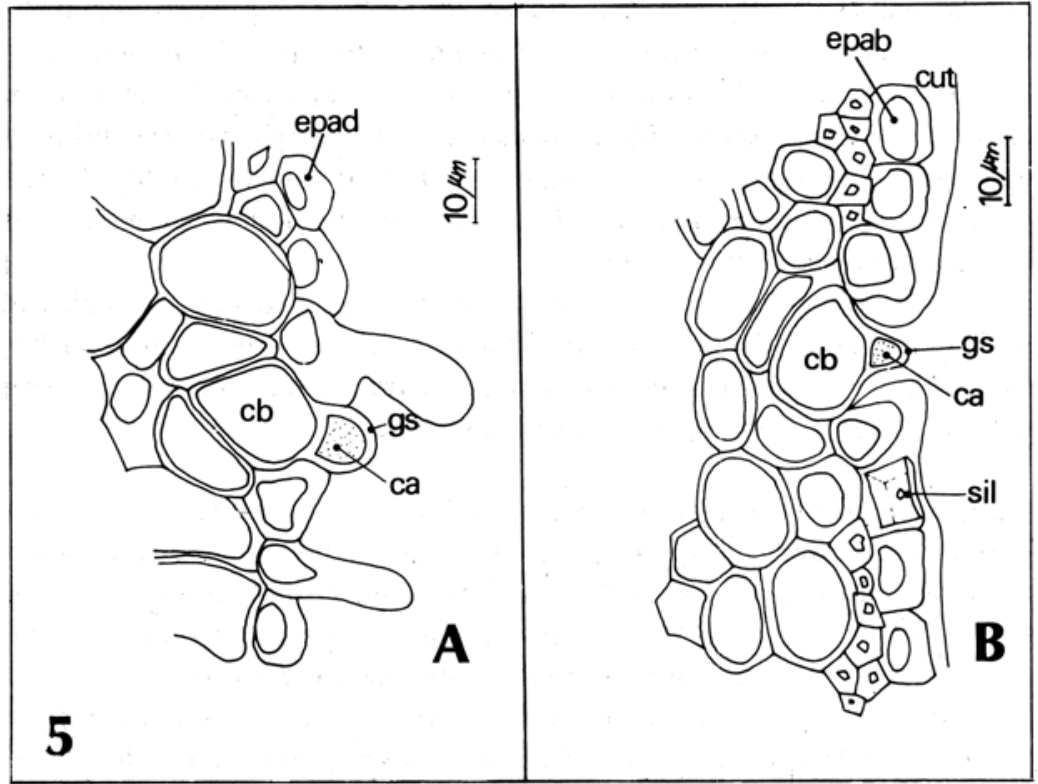

Figura 5: Spartina densiflora. Glândula de sal em corte transversal.

(A) gs: glândula de sal; epad: epiderme abaxial; cb: célula basal; ca: célula apical.

(B) gs: glândula de sal; epad: epiderme abaxial; cb: célula basal; ca: célula apical; cut: cutícula; sil: célula com corpo silicoso.

observada no citoplasma da g!ânudula de sal e células do mesofilo que a rodeiam. A célula apical apresenta parede celular mais espessa que a parede da célula basal, enquanto que a cutícula que recobre a glândula é delgada, diferenciando-se em espessura da cutícula que recobre as células epidérmicas.

Em corte transversal, a lâmina foliar apresenta feixes vasculares de primeira e segunda ordem. Os feixes vasculares são circundados por bainha dupla. A bainha vascular interna é formada por células pequenas e lignificadas, sem cloroplastídios e interrompida adaxialmente. A bainha externa é parenquimática, de células grandes com paredes delgadas e grandes cloroplastídios e ocorre lateralmente aos feixes vasculares, projetando-se para dentro das ramificações. O clorênquima radiado ocorre junto à bainha parenquimática externa e a acompanha em toda sua extensão. Esse tecido é formado por células pequenas de paredes extremamente delgadas, com cloroplastídios pequenos e vacúolos visíveis; contata-se "Sindrome de Kranz" (Figura 3). Nas ramificações maiores e em toda extensão da face abaxial, entre a epiderme e os feixes vasculares, aparecem células poliédricas incolores, sem espaços intercelulares, nas quais não se distinguem vacúolos e cloroplastídios. Estas células 
possuem paredes levemente espessadas e lignificadas, que constituemum parênquima com células incolores. Com a maturidade das folhas, e provavelmente longos períodos de estiagem a que a planta é submetida, a lignificação aumenta consideravelmente. Com o exposto acima observa-se que nas ramificações maiores ocorre centralmente ao parênquima incolor a formação de um cordão esclerenquimático de posição perpendicular aos feixes vasculares. Na face abaxial ocorre lignificação em todas as células parenquimáticas incolores, formando calotas esclerenquimáticas, que se estendem até os feixes vasculares.

No terço inferior da lâmina foliar, observam-se espaços intercelulares de origem lisígena intercalando-se com os feixes vasculares, sendo comum nas folhas basais (Figura 3). $\mathrm{O}$ mesmo não foi constatado para o terço mediano e superior da lâmina foliar onde o tecido apresenta-se compacto.

Bainha foliar: Em corte transversal, a epiderme da superfície adaxial apresenta células pouco espessadas. Entretanto, a epiderme da superfície abaxial apresenta células epidérmicas muito espessadas, células com corpos silicosos e espinhos esparsos (Figura 6). Os espinhos são unicelulares, de paredes espessadas, de base a largada, em contato com células lignificadas situadas abaixo da epiderme. A porção emergente do espinho é alongada com ápice afilado. Os feixes vasculares são de primeira e segunda ordem, totalmente circundados por uma bainha de células lignificadas. $O$ mesofilo é formado por células parenquimáticas, com paredes pouco espessadas e lignificadas, sem espaços intercelulares. Há cloroplastídios, esparsamente distribuídos nas células parenquimáticas que circundam os feixes vasculares. Abaixo da epiderme abaxial ocorre de uma a duas camadas de células lignificadas, interrompidas por calotas de fibras esclerenquimáticas na posição dos feixes vasculares. Amplos espaços intercelulares de origem lisígena intercalam-se aos feixes vasculares (Figura 6).

Em vista frontal, a superfície abaxial apresenta células longas com paredes celulares muito espessadas e sinuosas. As células curtas são silico-suberosas intercalando-se à células longas nas faixas costais e intercostais. A forma e a distribuição das células silico-suberosas é semelhante a lâmina foliar. Nas faixas intercostais encontram-se distribuídos estômatos, glândulas de sal e espinhos. A superfície adaxial apresenta células longas e curtas com paredes delgadas e sinuosas, sem pontuações e poucos estômatos esparsamente distribuídos.

Rizoma: O rizoma é fistuloso, cilíndrico, altamente lignificado e recoberto por catáfilos membranáceos. Em corte transversal os catáfilos apresentam-se semelhantes a bainha foliar, entretanto a epiderme aparece com células lignificadas inclusive a célula apical da glândula de sal. Em corte transversal, o rizoma apresenta epiderme com células pequenas e lignificadas, intercaladas irregularmente por células contendo corpos silicosos recobertos por cutícula. No córtex observa-se uma faixa subepidérmica composta por quatro a seis camadas de células e amplos espaços intercelulares de origem lisígena. $O$ cilindro central inicia-se por uma afaixa esclerenquimática, que se projeta para dentro dos espaços intercelulares no seu limite 


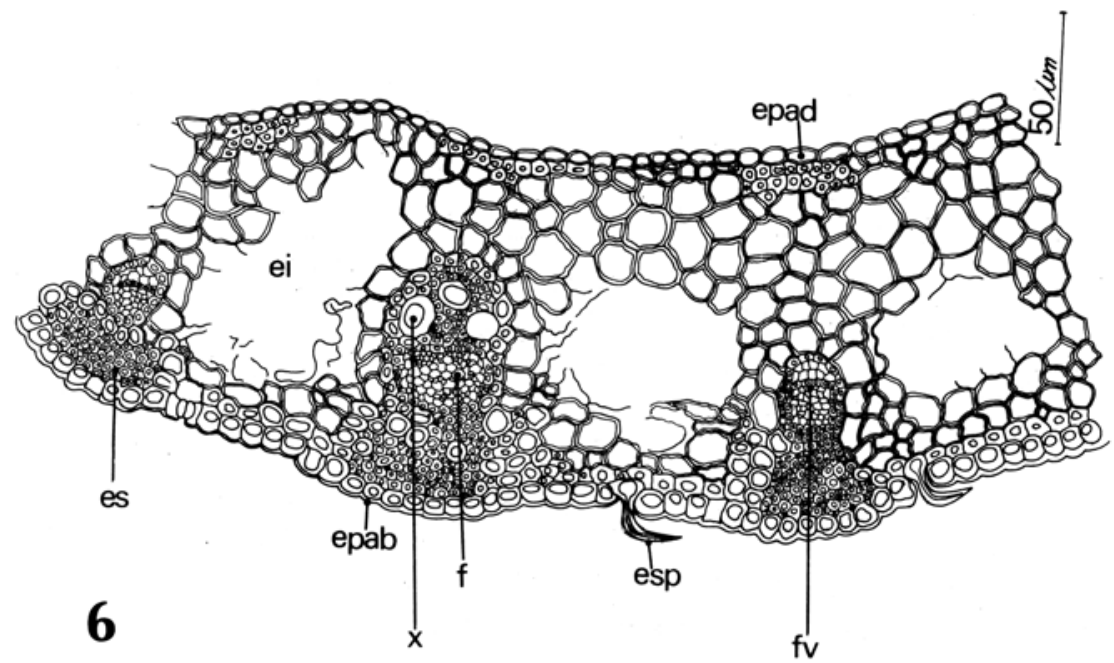

Figura 6: Spartina densiflora. Corte transversal da bainha foliar. ei: espaços intercelulares; epad: epiderme adaxial; epab: epiderme abaxial; es: calota esclerenquimática; esp: espinho; fv: feixe vascular; f: floema; $x$ : xilema.

externo. Os feixes vasculares são do tipo colateral, estando o anel mais externo incluído na faixa esclerenquimática e os restantes envolvidos por parenquima. A região da medula é ocupada por uma grande cavidade central (Figura 7).

Raiz: Em corte transversal, de raiz curta e longa, as epidermes estão constituídas por células grandes de paredes delgadas destituídas de cutícula (Figura 8a). No córtex, sustentando a epiderme, encontram-se de cinco a seis camadas de células, onde as duas mais internas apresentam-se levemente suberizadas. Internamente, ocorrem grandes espaços intercelulares de origem lisigena, que ocupam quase à totalidade do córtex, onde observam-se restos de paredes celulares (Figura 8 e 9). A região situada entre os espaços intercelula res e a endoderme é ocupada por duas a três camadas de células altamente lignificada, e a endoderme de raízes longas apresenta espessamento em forma de U (Figura $8 b$ ), enquanto em raízes curtas apresenta-se muito espessada (Figura 9b). O cilindro é limitado por um periciclo de uma camada de células esclereificadas nas regiões mais velhas das raízes. Cordões de xilema alternam-se com floema. Os cordões xilemáticos não alcançam o centro do cilindro vascular, que é ocupada por uma medula. A região da medula é formada por células arredondadas, lignificadas, apresentando pequenos espaços intercululares. De uma maneira geral não se observam diferenças anatômicas entre raízes longas e curtas (Figura 8 e 9). 


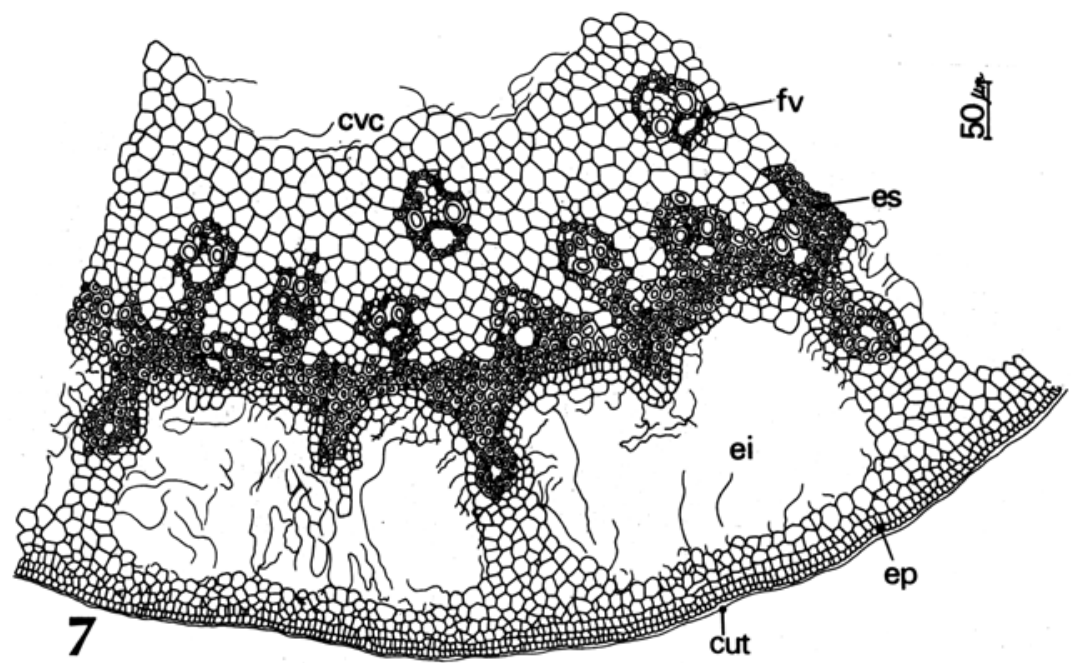

Figura 7: Spartina densiflora. Corte transversal do rizoma. cvc: cavidade central; cut: cutícula; ei: espaços intercelulares; ep: epiderme; es: faixa esclerenquimática; fv: feixe vascular.

Anaerobiose. A presença de espaços aerenquimatosos lisígenos nas folhas, que se estendem ao rizoma e as raízes de Spartina densiflora, demonstra a adaptação desta gramínea para viver em condições de alagamento. Esta observação também foi feita para Spartina townsendii (Sutherland \& Eastwood 1916), Spartina patens (Aiton.) Mulh. e Spartina alterniflora (Anderson, 1974) e Distichlis spicata (Hansen et al., 1976). Segundo Dacey (1981) e Drew (1983), essa adaptação permite à planta crescer em condiçōes anaeróbicas do solo, pois o alagamento preenche os espaços intersticiais, causando diminuição na difusão de oxigênio, o que cria condições adversas à sobrevivência. Diante do que supomos que o fluxo de gases pelos espaços intercelula res ga rantiria o suprimento de oxigênio nas raízes, o que asseguraria uma respiração aeróbica em condições de anaerobiose. Essa ventilação interna capacitaria um ajuste metabólico, evitando a produção de etanol através da respiração anaeróbica.

Xerofitismo e Halofitismo. Spartina densiflora, apresenta-se anatomicamente adaptada às condições estressantes do ambiente que se caracteriza pela alta salinidade e alagamento. Prisco (1980) relata que as altas concentrações de sais em solos alagados causa uma diminuição na permeabilidade radicular, levando a planta à seca fisiológica.

Dentro das adaptações observadas, na superfície adaxial das folhas ocorrem estômatos protegidos por papilas epidérmicas simples. Esse caracter constitui-se em uma novidade em termos anatômicas para o gênero Spartina, uma vez que 


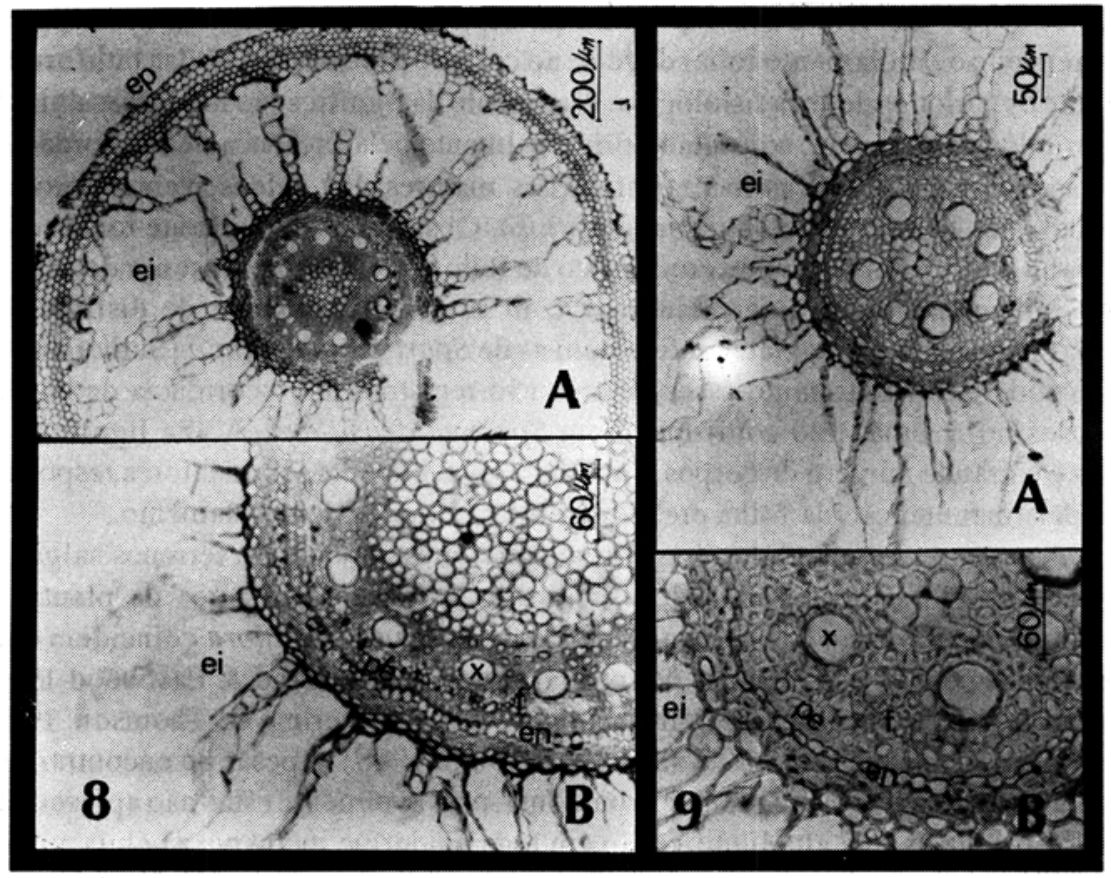

Figura 8: Spartina densiflora. Corte transversal da raiz longa de fixaçāo.

(A) aspecto geral mostrando que os espaços intercelulares ocupam quase a totalidade do córtex da raiz.

(B) aspecto do cilindro vascular. ei: espaços intercelulares; ep: epiderme; en: endoderme; pe: periciclo; f: floema; $x$ : xilema.

Figura 9: Spartina densiflora. Corte transversal da raiz curta de absorção. (A e B) aspectos do cilindro vascular; ei: espaço intercelular; en: endoderme; pe: periciclo; f: floema; $x$ : xilema. 
se conhecia apenas estômatos protegidos por papilas ramificadas em Spartina townsendii (Sutherland \& Eastwood 1916), Spartina alterniflora $\mathrm{e}$ S. patens(Anderson 1974). O enrolamento foliar, que determina a redução da superfície de transpiração e a aproximação das papilas epidérmicas, presentes na superfície adaxial, formam verdadeiras câmaras. A formação dessas câmaras onde se localizam, os estômatos protegidos por papilas, consideramos como uma proteção extra à dessecação. Esse mesmo fato também foi explicado por Hansen et al. (1976) para Distichlis śpicata. Por outro lado Sutherland \& Eastwood (1916), Andrade (1967) e Dawes (1981) sugerem que o enrolamento foliar deve-se ao colapso hídrico das células buliformes, durante os períodos de seca fisiológica. O aumento da lignificação nas folhas durante os períodos de estiagem, constatado principalmente pela presença de um cordão de células esclerenquimáticas nas ramificações maiores dos sulcos, vem reforçar o aspecto xero-halofítico de Spartina densiflora. Observação semelhante foi descrita por Fahn (1974), para o caule xeromórfico de Retoma reatam. A presença de células curtas silico-suberosas, intercalando-se com as células longas e de distribuição regular na superfície adaxial, confere com as de Spartina townsendii (Sutherland \& Eastwood 1916). Entretanto esses autores não registraram a ocorrência de corpos silicosos no rizoma, fato confirmado em Spartina densiflora. A alta lignificação foliar e o grande número de corpos silicosos provavelmente sejam fatores responsáveis pela manutenção da folha ereta durante os períodos de enrolamento.

A presença de glândulas de sal assegura o crescimento em terrenos salgados proporcionando secreção ativa de excesso de sal nas partes aérea da planta. A estrutura e distribuição das glândulas de sal de Spartina densiflora coincidem com as descritas para outras espécies do mesmo gênero (Sutherland \& Eastwood 1916; Anderson 1974; Skelding \& Winterbotham 1939; Levering \& Thomson 1971; Thomson 1975; Liphschitz \& Waisel 1982 e Fahn 1988). Apesar de encontrarmos glândulas nos catáfilos que recobrem o rizoma, provavelmente estas não apresentam funcionabilidade pela alta lignificação em toda epiderme inclusive a célula apical.

Algıns aspectos estruturais da glândula de sal de Spartina densiflora, como a parede espessada da célula apical e a cultícula que a recobre apresentando-se mais delgada que a cutícula das células epidérmicas adjacentes, coincidem com o padrão a natômico cloridóide (Amarasinghe \& Watson 1988). Além disso, constata-se uma maior densidade no citoplasma ao nível do pescoço da célula basal. Levering \& Thomson (1971) e Thomson (1975), relatam as mesmas observações para Spartina folios $a$ através da análise ultra-estrutural, porém não fizeram referências à espessura da parede da célula apical. A posição aprofundada da glândula de sal de Spartina densiflora é um aspecto também referido para o padrão cloridóide, e apontado como as de maior eficiência no processo de secreção de sal (Liphschitz \& Waisel 1982 e Amarasinghe \& Watson 1988 e 1989).

Parece-nos válido, sugerir estudos ao microscópio eletrônico, da glândula de sal de Spartina densiflora a fim de constatar a possível presença de membranas divisórias na célula basal. Pois, Oross et al. (1985) e Amarasinghe \& Watson (1989) atribuem a atividade secretória das glândulas de sal do tipo cloridóide com a presença 
de membranas divisórias na célula basal. Além disso, a densidade citoplasmática ao nível do "pescoço" da célula basal de Spartina densiflora, acreditamos que possa estar relacionada à presença de membranas divisórias. No entanto, Fahn (1988) atribui a secreção de sal a atividade simplástica e apoplástica, o que poderia explicar o provável mecanismo de secreção de sal através da espessa parede da célula apical.

A presença de glândula secretora de sal e o aumento da complexidade morfoanatômica, como alta lignificação, estômatos protegidos por papilas, enrolamento foliar e espaços intercelulares nas folhas, rizoma e raízes são características xeromórficas e halofiticas que permitem Spartina densiflora crescer em solos alagados, anaeróbicos e salgados.

\section{Agradecimentos}

A professora Anita Ursula G. Görgen pela confecção de lâminas permanentes. Ao professor Fernando D'Incao pelos dados ambientais da área em estudo e a professora Jaci M.B. Saraiva pelos dados pluviométricos. Aos professores Joaber Pereira Junior e Clélia Maria P. Pereira pelas sugestões ao manuscrito.

\section{Referências Bibliográficas}

AMARASINGHE, V.\& L. WATSON. 1988. Compa rative ultrastructure of microhairs in grasses. Bot. J. Linn. Soc. 98 (4): 303-319.

AMARASINGHE, V. \& L. WATSON 1989 . Variation in salt secretory activity of microhairs in grasses. Aust. J. Plant Physiol. 16 (2): 219-229.

ANDERSON, C.D. 1974. A review of structure in several North Carolina salt marsh plants. In: REINOLD, R.J. \& QUEEN, W.H. Ecologyof halophytes. Academic Press., London, p. 307-317.

ANDRADE, M.A.B. 1967. Contribuição ao conhecimento da ecologia das plantas das dunas do litoral do estado de São Paulo. Bol. Fac. Fil., Ciênc. Let. USP., S. Bot. 305 (22): 3-170.

BEÇAK, W. \& J. PAULETE 1976. Técnicas de citologia e histologia. Livros Técnicos e Científicos Editora S.A., Rio de Janeiro. p. 230.

COUTINHO, R. 1982. Taxonomia, distribuição, crescimento sazonal, reprodução e biomassa das algas bentônicas no estuário da lagoa dos Patos (RS). Tese de mestrado em Ciências. Oceanografia biológica, Universidade do Rio Grande, Rio Grande. p. 25.

DACEY, J.W.H. 1981. How aquatic plants ventilate. Oceanus 24 (2): 43-51.

DAWES, C.J. 1981. Marine botany. Wiley-Inter Science, New York, p. 494-515.

DREW, M.C. 1983. Plant injury and adaptation to oxigen deficiency in the root environment: a review. Plant and soil, 75: 179-199. 
FAHN, A. 1974. Anatomia Vegetal. 17 - Madrid - 5, H. Blume ediciones, Rosario, p. 247-254.

FAHN, A. 1988. Secretory tissues in vascular plants. New Phytol. 108: 229-259.

HANSEN, D.J.; P.DAYANANDAN; P. KAUFMAN \& J.D.BROTHERSON. 1976. Ecological adaptations of salt marsh grass, Distichlisspicata (Granimeae), and environmental factors affecting its growth and distribution. Amer. J. Bot. 63 (5): 635-650.

JOHANSEN, D.A. 1940. Plantmicrotechinique. MacGraw-Hill Publishing Company LTD., Bombay, p. 198.

LEVERING, A.C. \& W.W. THOMSON. 1971. The ultrastructure of the salt glands of Spartina foliosa. Planta (Berl.) 97: 183-196.

LIPHSCHITZ, N. \& Y. WAISEL. 1982. Adaptation of plants to saline environments: salt excretion and giandular structures. In: SEN, D.N. \& K.S. RAJPUROHIT. Contributions to the ecology of halophytes. Dr. W. Junk Publishers, The Hague. Boston, p. 197-214.

MAAZ, G.J.\&E.VAGAS. 1951. A new method for staining of cellulose and lignified cell-walls. Mikroskopie 16 (1-2): 40-43.

OROSS,J.W.;R.T.LEONARD \& W.W.THOMSON. 1985. Flux rate and a secretion model for salt glands of grasses. Israel J. Bot., 34: 69-77.

PRISCO, J. T.1980. Alguns aspectos da fisiologia do stress salino. Revta. brasil. Bot. 3: 85-94.

SKELDING, D. \& J. WINTERBOTHAM. 1939. The structure and development of the hydathodes of Spartina townsendii Groves. New. Phytol 38: 69-75.

SUTHERLAND, G.K. \& A. EASTWOOD. 1916. The physiological anatomy of Spartina townsendii. Ann. Bot. 30: 333-351.

THOMSON, W.W.1975. The structure and function of salt glands.In: POLJAKOFFMAYBER, A. \& GALE, J. Plants in saline environments. Chapmen e Hall, London, p. 118-146. 